\title{
Analysis of the Processes in Spent Fuel Pools in Case of Loss of Heat Removal due to Water Leakage
}

\author{
Algirdas Kaliatka, Viktor Ognerubov, Virginijus Vileiniškis, and Eugenijus Ušpuras \\ Laboratory of Nuclear Installations Safety, Lithuanian Energy Institute, Breslaujos 3, 44403 Kaunas, Lithuania \\ Correspondence should be addressed to Algirdas Kaliatka; algis@mail.lei.lt
}

Received 31 January 2013; Revised 23 April 2013; Accepted 7 May 2013

Academic Editor: Arkady Serikov

Copyright ( 2013 Algirdas Kaliatka et al. This is an open access article distributed under the Creative Commons Attribution License, which permits unrestricted use, distribution, and reproduction in any medium, provided the original work is properly cited.

\begin{abstract}
The safe storage of spent fuel assemblies in the spent fuel pools is very important. These facilities are not covered by leaktight containment; thus, the consequences of overheating and melting of fuel in the spent fuel pools can be very severe. On the other hand, due to low decay heat of fuel assemblies, the processes in pools are slow in comparison with processes in reactor core during LOCA accident. Thus, the accident management measures play a very important role in case of some accidents in spent fuel pools. This paper presents the analysis of possible consequences of fuel overheating due to leakage of water from spent fuel pool. Also, the accident mitigation measure, the late injection of water was evaluated. The analysis was performed for the Ignalina NPP Unit 2 spent fuel pool, using system thermal hydraulic code for severe accident analysis ATHLET-CD. The phenomena, taking place during such accident, are discussed. Also, benchmarking of results of the same accident calculation using ASTEC and RELAP/SCDAPSIM codes is presented here.
\end{abstract}

\section{Introduction}

According to the NRC data [1], the probability of a loss of coolant from spent fuel storage pool is about $10^{-6}$ per pool per year. The consequences can be very severe and a huge amount of radioactive materials can be released to the environment because the spent fuel pools are not covered by containment as the reactor core.

As it is noted in the Operating Experience Feedback Report "Assessment of Spent Fuel Cooling" [2], during operation time, two losses of spent fuel pool coolant inventory events occurred, and decrease of water level by $1.5 \mathrm{~m}$ was registered. These real events were terminated by operator action, when approximately $6 \mathrm{~m}$ of water remained above the stored fuel. In the case without operator actions, the water loss could have continued, that could lead to the severe accident in spent fuel pool. During station blackout accident at Fukushima NPP after tsunami disaster in March 11, 2011, the water level in SFP of Unit 4 decreased more than $6.5 \mathrm{~m}$, down to the $1.5 \mathrm{~m}$ above the top of SFA. The mitigation measures, water injection from nondesign sources, allow to prevent a severe accident (damage of fuel rods) in SFP of Fukushima NPP Unit 4.
The possible consequences of water loss due to leakage and late operator actions (water injection to the spent fuel pool after fuel heat up) are evaluated in this paper. The evaluation of this accident was performed for Ignalina NPP Unit 2 spent fuel pool, assuming the possible highest decay heat generation in SFP (such situation was at the moment of final shutdown of Ignalina NPP Unit 2). Such situation was analyzed, because it is very similar to the situation during the March 11, 2011 accident at Fukushima NPP Unit 4. The today situation at Ignalina NPP, with significantly decreased decay heat of spent fuel, is presented also. The developed models can be applied to SFP of other reactor types as well. Applying to the SFP of other reactors types, it is necessary to evaluate the real characteristics of SFP: water volume, possible leakage rate, and decay heat of fuel assemblies groups in SFP, and so forth.

The analysis of water leakage accident was performed using three computer codes designed for the severe accident analysis: ATHLET-CD, ASTEC, and RELAP/SCDAPSIM. All the thermal hydraulic models were developed as much as possible in the similar way, because the main idea of this paper was to evaluate the capability of these codes and to discuss the modelling approach. 


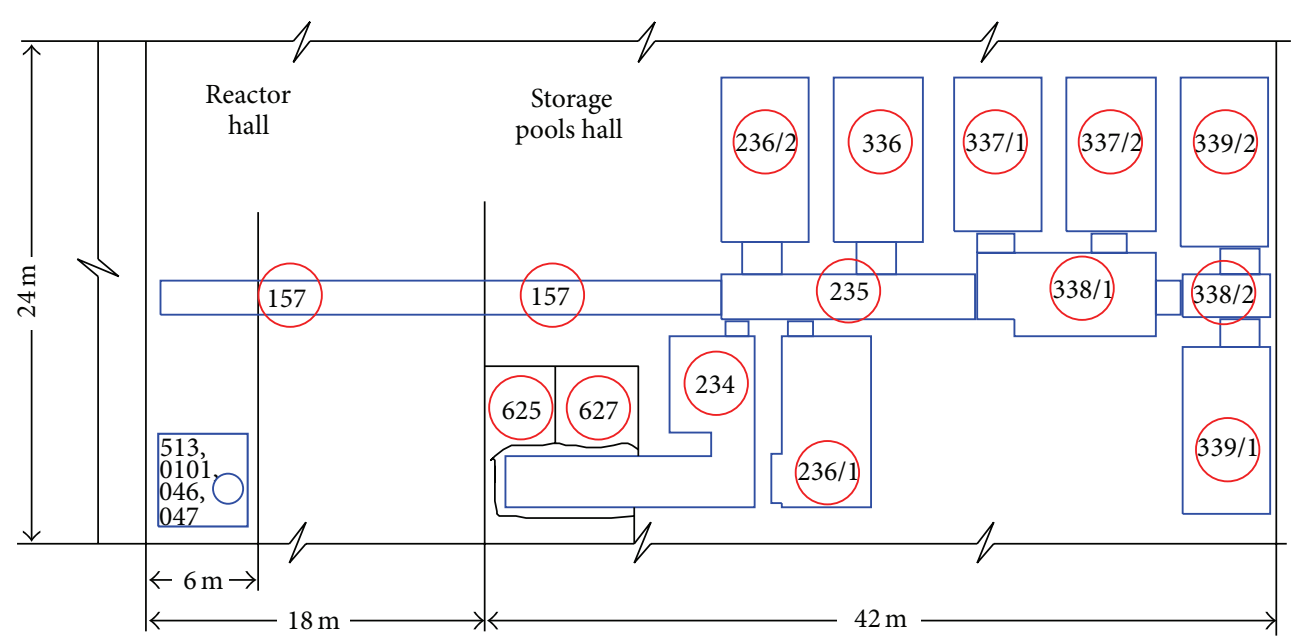

FIGURE 1: Layout of buildings in SFPs hall of Ignalina NPP Unit 2.

\section{Design of Spent Fuel Pools at Ignalina NPP and Developed Models}

At the Ignalina NPP (Lithuania), two Russian design channeltype graphite-moderated boiling water reactors (RBMK1500) were commissioned in 1983 and 1987. At present, both units are shut down for decommissioning (in 2004 and 2009). All assemblies of spent fuel are stored in the spent fuel pools (SFP) and in dry storage facility on site of the Ignalina NPP. Thus, the safety justification of spent fuel assemblies' storage in the SFP of Ignalina NPP is very important.

General description of Ignalina NPP spent fuel pool design, fuel characteristics, and estimation of decay power in SFP is presented in the paper [3]. The design of the RBMK reactor fuel rods differs very little from fuel elements manufactured for standard BWR-type reactors [4]. The core height of RBMK-1500 reactor is $7 \mathrm{~m}$. In order to achieve the required height, the RBMK fuel assembly consists of two fuel bundles placed one above the other. Each fuel bundle includes 18 fuel elements placed in two circles around the carrying rod. The outer diameter of fuel assembly is $79 \mathrm{~mm}$. For safe disposal of spent fuel bundles into the spent fuel pools and later in the dry storage facility, the leak tight fuel assemblies should be cut, separating fuel bundles and placing them in the shipping casks.

Each reactor unit at Ignalina NPP is equipped with a system of spent fuel pools (Figure 1). All process operations related to handling of the spent fuel are performed in the central hall or in the spent storage pools hall. Spent fuel pools of Ignalina NPP are designed for the following purposes:

(i) storage of non-cut spent fuel assemblies (SFAs) in deep compartments of storage pool (rooms 236/1 and 236/2);

(ii) storage of spent nuclear fuel in shipping casks in shallow compartments of the storage pool after cutting SFAs (rooms 336, 337/1, 337/2, 339/1, and 339/2).

The spent fuel assemblies, prepared to be cut in the "hot" cell, are accumulated in a separate pool (Room 234).
The loading of the shipping casks is performed in two pools (Rooms 338/1 and 338/2). Also, there are transport corridor (Room 235) for the transportation of SFAs and shipping casks between the pools and transport corridor (Room 157) for transportation of fuel assemblies between spent fuel hall and reactor hall. The whole complex of storage pools of the spent fuel storage and handling system comprises 12 pools (Figure 1). The reloaded fuel assemblies remain in the pool for at least a year, after which they may be removed to be cut (in "hot" cell) and then to be loaded into the 102 placed shipping casks. The shipping casks with spent fuel assemblies are stored in the storage pools until they are loaded into the protective casks CASTOR or CONSTOR to be further transported to the dry spent fuel storage facility. The detailed description of spent fuel pools in Ignalina NPP is presented in $[3,5]$.

The benchmarking analysis was performed using codes for analysis of severe accidents ATHLET-CD [6], ASTEC [7] and RELAP/SCDAPSIM [8]. The best estimate system thermal hydraulic code ATHLET-CD is developed for the analysis of reactor accidents with core degradation and includes modules for the simulation of core degradation, melting and relocation, release and transport of fission product and aerosol, and behaviour of debris bed. ASTEC code is a source term evaluation code with modular structure. A model developed using ICARE module of ASTEC V2.0R2 code is used in this paper. The ICARE module simulates the in-vessel core degradation: the behaviour of in-vessel structures, the formation and the evolution of liquid and solid mixtures, thermal hydraulics, and chemical reactions between materials. The RELAP/SCDAPSIM code is an integrated, mechanistic computer code, which models the progression of severe accidents in light-waterreactor nuclear power plants. The RELAP/SCDAPSIM is being developed at Innovative Systems Software as part of the international SCDAP Development and Training Program. RELAP/SCDAPSIM/MOD3.2 uses the publicly available SCDAP/RELAP5/MOD3.2 models. The entire spectrum of in-vessel severe accident phenomena, including reactorcoolant-system thermal-hydraulic response, core heat up, degradation and relocation, and lower-head thermal loads, 
TABLE 1: Parameters of SFA in SFP.

\begin{tabular}{lcccr}
\hline $\begin{array}{l}\text { Groups of SFAs in } \\
\text { model }\end{array}$ & $\begin{array}{c}\text { Amount of SFAs } \\
\text { in group }\end{array}$ & $\begin{array}{c}\text { Assumed storage } \\
\text { time in SFP }\end{array}$ & SFAs decay heat, W & Group power, kW \\
\hline ROD1 & 166 & 8 days & 5210 & 864.9 \\
ROD2 & 1182 & 137 days & 1281 & 1514.1 \\
ROD3 & 892 & 2 years & 489 & 436.2 \\
ROD4 & 5661 & 3 year & 254 & 1437.9 \\
\hline Total & 7901 & - & - & 4253 \\
\hline
\end{tabular}

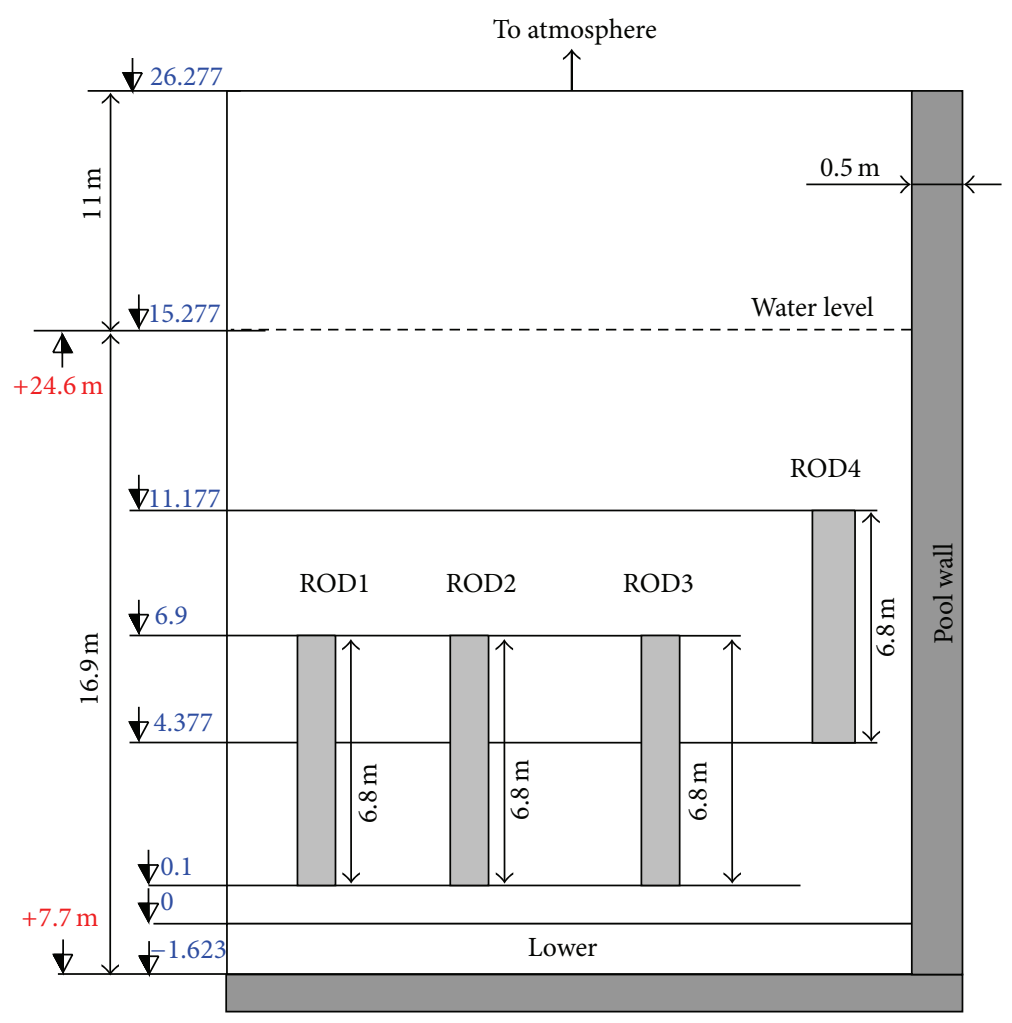

FIGURE 2: SFP and SFAs nodalization scheme in ASTEC model.

are treated in this code in a unified framework for both boiling water reactors and pressurized water reactors. The feasibility of RELAP/SCDAPSIM for modelling of lowpressure transients with the presence of noncondensable gases such as those occurring in spent fuel storage facilities is justified in the code developers' paper [8].

The ATHLET-CD and ASTEC code models of SFP and fuel bundles are based on the same philosophy: all rooms of SFP are modelled by single pool with 4 different groups of SFAs (see Figures 2 and 3). Also heat removal to the environment was evaluated through the SFP walls. However, some differences of evaluation of SFP hall and interaction with the environment in the ATHLET-CD and ASTEC model exist. In ASTEC model, the SFP and hall are modelled using single element in contradiction to the ATHLET-CD model, where SFP hall was modelled by TOPVOLUM element above the SFP and then connected to the environment, while in ASTEC model it is a direct connection of SFP to the environment. Heat removal from the outside of SFP in ATHLET-CD was modelled to the air flow, while in ASTEC model heat removal to the environment from the heat structure POOLWALL was assumed using the selected heat removal coefficient.

As it was mentioned, in the ATHLET-CD and ASTEC models, for the fuel modelling in SFP, all fuel assemblies were modelled by 4 equivalent groups of fuel assemblies: ROD1, ROD2, ROD3, and ROD4 with different decay heat levels (see Table 1). These levels of decay heat are in accordance with the condition, which was before the final shutdown of Ignalina NPP unit 2. It was assumed that shipping casks with spent fuel bundles are placed in SFP in two layers one above the other, according to the real shipping casks loadings scheme in the SFP [9]. In the SFP of Ignalina NPP the noncut SFAs and the fuel assemblies with higher level of decay heat are placed deeper in the SFP. Therefore the heat structure ROD4 is placed higher, comparing to ROD1, ROD2, and ROD3 (see Figures 2 and 3).

The SFP model for RELAP/SCDAPSIM code is very similar to ATHLET-CD code model; only one difference exists 


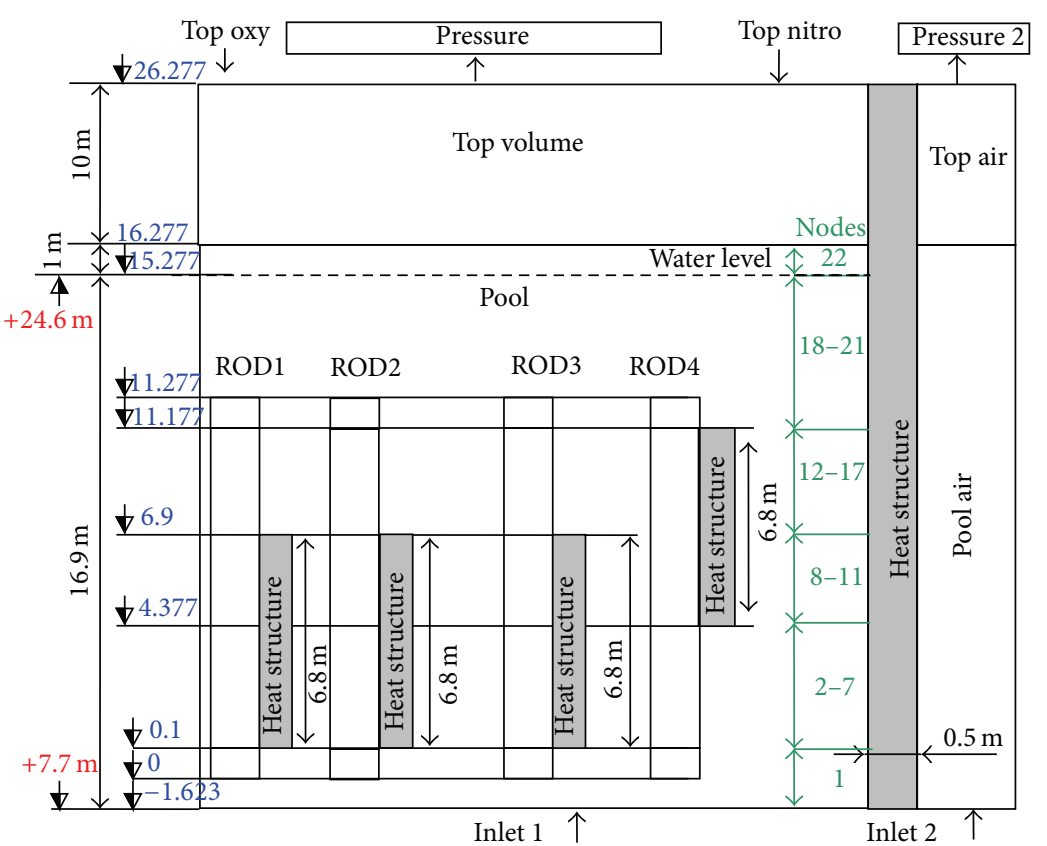

(a)

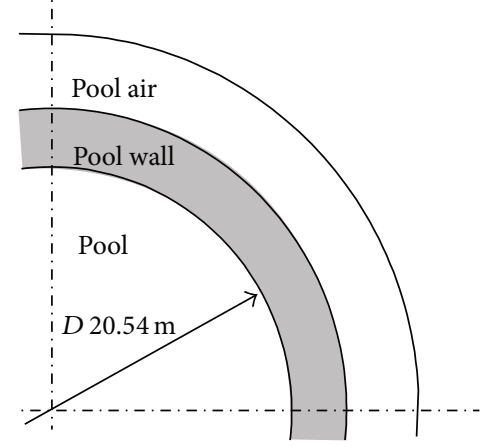

(b)

FIGURE 3: SFP and SFAs nodalization scheme in ATHLET-CD model.

TABLE 2: Comparison of SFP models for three different codes.

\begin{tabular}{|c|c|c|c|}
\hline Parameter & ATHLET-CD & ASTEC & RELAP/SCDAPSIM \\
\hline Total power of SFA, $\mathrm{kW}$ & & 4253 & \\
\hline Water level, $\mathrm{m}$ & & 16.9 & \\
\hline Water volume in SFP, $\mathrm{m}^{3}$ & & 5070 & \\
\hline Initial water temperature, ${ }^{\circ} \mathrm{C}$ & & 50 & \\
\hline Water leakage rate, $\mathrm{kg} / \mathrm{s}$ & & 21.111 & \\
\hline Water injection rate, $\mathrm{kg} / \mathrm{s}$ & & 27.8 & \\
\hline Time of water injection start, s & & 300000 & \\
\hline Number of SFP nodes & & 22 & \\
\hline Outside wall thickness, $\mathrm{m}$ & & 0.5 & \\
\hline Heat transfer by radiation & & evaluated & \\
\hline Oxidation reaction with air & & evaluated & \\
\hline Oxidation reaction with steam & & evaluated & \\
\hline Total hight of volume with air above water, $\mathrm{m}$ & 11 & 11 & 11 \\
\hline SFP hall height, $\mathrm{m}$ & 10 & 0 & 10 \\
\hline Height of air in SFP above water, $m$ & 1 & 11 & 1 \\
\hline Cooling of outside wall of SFP & $\operatorname{Air}\left(25^{\circ} \mathrm{C}\right)$ & Constant heat transfer coef. $\left(5 \mathrm{~W} / \mathrm{m}^{2}\right)$ & $\operatorname{Air}\left(25^{\circ} \mathrm{C}\right)$ \\
\hline Number of modelled SFA group in SFP & 4 & 4 & 1 \\
\hline
\end{tabular}

in fuel modelling - all fuel assemblies in RELAP/SCDAPSIM were modelled by one equivalent fuel rod "Fuel rod 1," with total decay heat $4253 \mathrm{~kW}$ (see Figure 4).

SFP models for three different codes comparison are presented in Table 2.

\section{Analysis of Spent Fuel Pool Dryout due to Water Leakage Using ATHLET-CD Code}

During the modelling of loss of water from the spent fuel pool due to water leakage accident, for the evaluation of worst possible consequences, the main assumptions in the model were used:

(i) the maximal amount of spent fuel assemblies is placed in the spent fuel pools;

(ii) total mass of uranium in SFPs (in 7901 SFA) is equal to $752,400 \mathrm{~kg}$;

(iii) the residual decay heat of SFAs is the maximal possible. It was assumed that the total decay heat in SFP is equal to $4253 \mathrm{~kW}$ - such power level was theoretically maximal during the Ignalina NPP Unit 2 operation; 


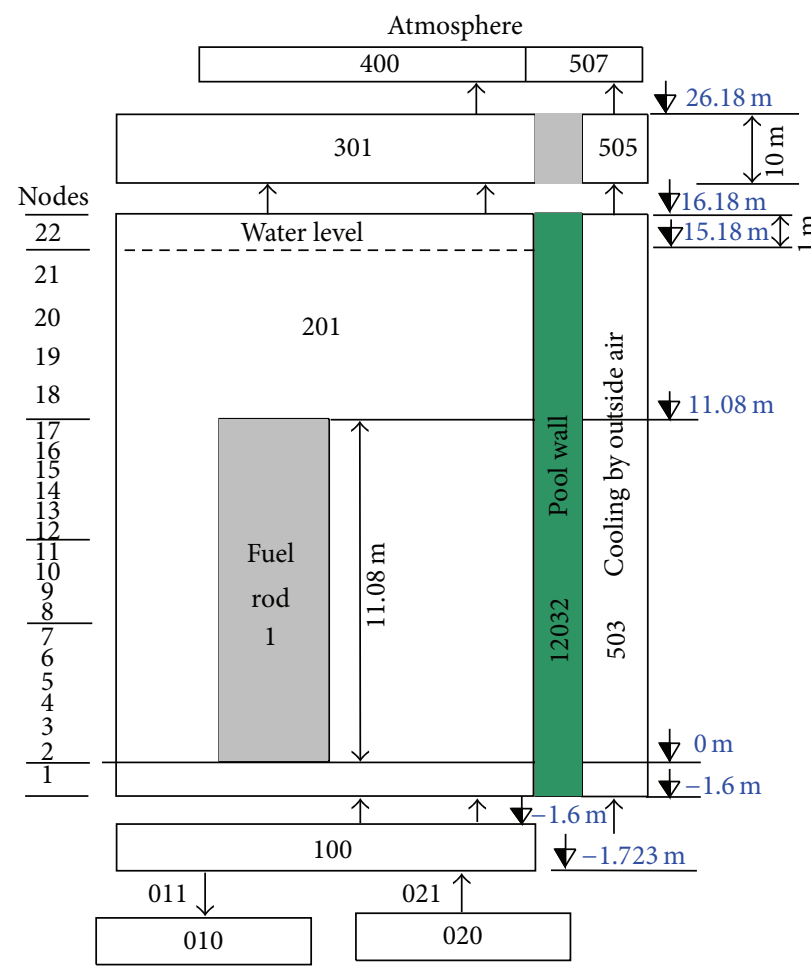

FIGURE 4: SFP and SFAs simplified nodalization scheme in RELAP/SCDAPSIM model.

(iv) initial water volume in SFP is equal to $5070 \mathrm{~m}^{3}$;

(v) water level is $16.9 \mathrm{~m}$ from the bottom of SFP;

(vi) initial water temperature is $50^{\circ} \mathrm{C}$;

(vii) the maximal possible water leakage through damaged drainage pipe is assumed $(21.11 \mathrm{~kg} / \mathrm{s})$.

The main goal of this paper is to discuss the processes in SFP during the loss of water due to leakage in pools. Also the accident mitigation measure, the water injection to the spent fuel pool after fuel heat up, is discussed. It was assumed that after $300000 \mathrm{~s}$ from accident beginning SFP auxiliary water makeup system starts operation. The flow rate of injected water $27.8 \mathrm{~kg} / \mathrm{s}$ was selected taking into account the capacity of SFP water makeup system in Ignalina NPP.

Water leakage leads to water level decrease in the pool (see Figure 5). The sequence of analyzed accident will be the following:

(i) $t=0 \mathrm{~s}$-initiation of water leakage in the SFP;

(ii) $t=60,000 \mathrm{~s}$-water level decreases down to the top of SFA (fuel uncovering and heat up in air starts);

(iii) $t=215,000 \mathrm{~s}$-water level decreases down to the bottom of SFA (all SFAs are fully uncovered);

(iv) $t=235,000 \mathrm{~s}$-water level decreases down to the bottom of SFP (stop of water leakage from SFP);

(v) $t=300,000 \mathrm{~s}$-water injection starts;

(vi) $t=315,000 \mathrm{~s}$-water level increases up to the bottom part of SFA;

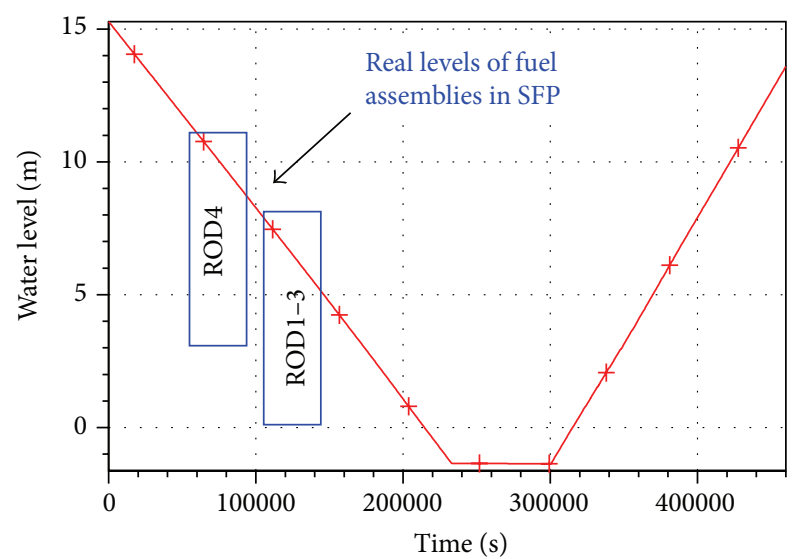

FIGURE 5: Water level in spent fuel pools.

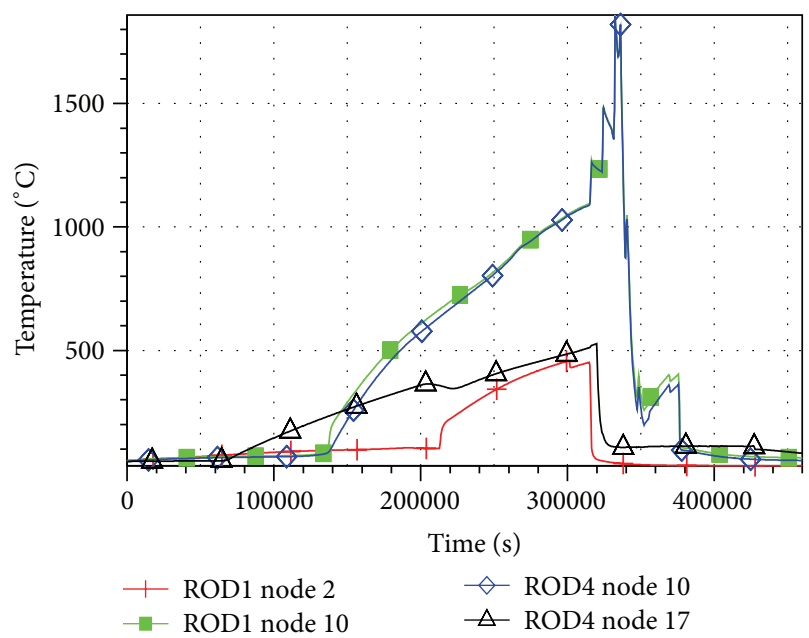

FIGURE 6: Fuel temperature in SFAs with different storage period at different elevations: node 2-at elevation $1.17 \mathrm{~m}$, node 10 -at elevation $5.64 \mathrm{~m}$, node 17-at elevation $10.82 \mathrm{~m}$ (elevations from the bottom of SFA).

(vii) $t=420,000 \mathrm{~s}$-water level increases up to the top of SFA (all SFAs and molten material are cooled down).

As it is shown in Figure 5, all the SFAs are uncovered at time moment $t=215,000 \mathrm{~s}(\sim 60 \mathrm{~h})$, stop of water leakage assumed at time moment $235,000 \mathrm{~s}$, when small amount of water is still presented in bottom part of SFP, water injection to the pool is started at time moment $t=300,000 \mathrm{~s}(\sim 83 \mathrm{~h})$ after the beginning of the accident.

After the beginning of fuel assembly uncovering $(t=$ $60,000 \mathrm{~s})$, the fuel heat up process starts. The behaviour of fuel temperatures is presented in Figure 6. As it is shown in the presented figure, the fuel temperatures of all equivalent groups of rods at the same level (in the same node) are approximately the same. It is due to very slow heatup process and due to convective heat transfer between SFAs in the pool. Temperature in the top part of SFAs (ROD4 node 17 on Figure 6) increases slowly in comparison with the central part of SFAs (ROD1 and ROD4 node 10) due to lower decay heat in 
ROD4 and due to cooling down by the air from the top part of SFP room (TOPVOLUM).

After temperature increase up to the $700^{\circ} \mathrm{C}(t=$ about 210,000 s) slow exothermic oxidation reaction of fuel cladding with air starts. The maximal heat generation due to this oxidation process reaches $1.1 \mathrm{MW}$ at time moment $300,000 \mathrm{~s}$ (Figure 7(b)). This oxidation leads to the air suction from the top part (TOPVOLUM) and cooling down of the top part of SFA (see insignificant temperature decrease in ROD4 node 17 at time moment 210,000 s in Figure 6). After the water injection starts $(t=300,000 \mathrm{~s})$, the decrease of temperature in the bottom part of SFP begins. This leads to air cooldown in this part and air flow increase from the top to the bottom. In turn, this leads to small decrease of fuel cladding temperature (see fuel temperature in node 2 ROD1 in time interval $t=300,000-315,000 \mathrm{~s}$ ). At the same, time the sharp slowdown of oxidation in steam process and rapid decrease of heat generation occur (see Figure $7(\mathrm{~b})$ at time moment $t=300,000 \mathrm{~s}$ ).

Maximal temperatures in the central part of SFAs reached about $1900^{\circ} \mathrm{C}$. Fast increase of temperature at $t=315,000 \mathrm{~s}$ (Figure 6) occurs in the central part of SFA due to intensive steam-zirconium reaction after the increase of the amount of available steam for oxidation. Steam in SFP starts to generate intensively at about $315,000 \mathrm{~s}$ when water level increases up to the bottom part of SFA (Figure 5) and contact with hot SFAs (temperature of the bottom part of SFAs is about $500^{\circ} \mathrm{C}$ ) occur. The generated steam cools down the SFAs in the very bottom and top parts, because the amount of generated heat in these parts is relatively low (as it is shown in Figure 6, the temperatures in node 2 of ROD1 and node 10 of ROD1 are below the temperatures, when the fast exothermic steamzirconium reaction process can start).

When the fast steam generation occurs (at time moment $t>315,000 \mathrm{~s}$ ), temperature of fuel in central part reaches $1200^{\circ} \mathrm{C}$, which leads to fast reaction of steam with zirconium from fuel claddings. At the same time, the significant amount of heat is generated due to the exothermic oxidation process (Figures 7(a) and 7(c)). Maximal heat generation due to oxidation of fuel rods claddings with steam reached $80 \mathrm{MW}$.

Starting from the time moment $t=210,000 \mathrm{~s}$, due to the increase of fuel rods temperature up to $700^{\circ} \mathrm{C}$, slow cladding oxidation process in steam and hydrogen generation starts (Figure 8). Up to the moment of water injection the total amount of generated hydrogen is equal to the $300 \mathrm{~kg}$. Later (from the 315,000 s), after fast oxidation process due to hot cladding (temperature more than $1200^{\circ} \mathrm{C}$ ) reaction with steam, a rapid increase of temperature begins (Figure 6) and a huge amount of hydrogen is generated (Figure 8). Sum of generated hydrogen mass reaches $1900 \mathrm{~kg}$. Oxidation takes place in the central part of SFA because the fuel cladding temperature in the very bottom and top parts of SFAs is approximately $500^{\circ} \mathrm{C}$. This is considerably below the temperature of fast oxidation threshold $\left(1200^{\circ} \mathrm{C}\right)$.

After the fuel element claddings damage, release of volatile fission products to the SFP room and later to the environment starts. The calculation of released mass of fission product species and power of these species for the case of uncompensated leakage from SFP is presented in the paper [5].

\section{Possible Consequences of Water Leakage Accident in SFP of Ignalina NPP at Present Days (4 Years after Final Shut Down of Reactor)}

The worst possible severe accident consequences of Ignalina NPP SFP, water leakage at maximal decay heat during operation period of NPP, was presented in the section above. The consequences of severe accident presented above are more or less the same for all water cooled reactors types during operation of NPP. The decay heat of SFA in SFP decreases exponentially during the time of storage in SFP. Therefore, time factor is very important for the possible consequences of water leakage accident from SFP.

The reactor of Unit 2 of Ignalina NPP was shut down at the end of 2009; therefore, at the end of 2013 it will be 4 years of final reactor shutdown. Therefore, in this paper both cases were analysed: the possible consequences of water leakage accident during operation period of Ignalina NPP to show the severity of such accident and possible consequences of the same accident for situation after 4 years after final shutdown of Ignalina NPP Unit 2 reactor.

In this section the possible consequences of the water leakage accident at Ignalina NPP after 4 years after final shutdown was presented.

The only difference from the model described above is that the maximal possible decay heat power of fuel after 4 years is $809.6 \mathrm{~kW}$ (see Table 3) and empty pool (fuel is cooled by air only) as initial conditions were assumed. This was done because in case of low residual heat in SFP, water absence in the bottom part of pool becomes very important to the maximal reached temperatures of SFA especially for the bottom part of SFA. Also in contradiction with the scenario presented in the section above (water leakage and then water injection), no water injection was assumed to show that fuel in SFP can be cooled by air only.

On the figures below (Figures 9 and 10), temperatures at different levels of SFA in SFP were presented. It should be noted that according to the technical data of Ignalina NPP, SFA damage of fuel elements claddings occurs if temperatures reached $700^{\circ} \mathrm{C}$.

As it is shown on the after mentioned figures maximal temperature of fuel in SFP in long term was at about $540^{\circ} \mathrm{C}$ (Figure 9) in ROD1 element, which represents fuel with highest decay heat rate in SFP (see Table 3).

The results of calculations show that in case of water leakage accident at Ignalina NPP 4 years after Final shut down of reactor fuel claddings will remain intact and release is not expected to the environment. Also generation of hydrogen does not occur and no dangerous increase of concentration of hydrogen in SFP is expected during the loss of water accident at Ignalina NPP on "today" stage. But it should be noted that structures of SFP (metals, concrete, etc.) cannot be operated safely at such temperature range; therefore, safe operation of SFP at Ignalina NPP should be ensured until the final fuel 
TABle 3: Parameters of SFA in SFP (today situation).

\begin{tabular}{lcccc}
\hline $\begin{array}{l}\text { Groups of SFAs in } \\
\text { model }\end{array}$ & $\begin{array}{c}\text { Amount of SFAs } \\
\text { in group }\end{array}$ & $\begin{array}{c}\text { Storage time in } \\
\text { SFP }\end{array}$ & SFAs decay heat, W & Group power, kW \\
\hline ROD1 & 166 & $\sim 4$ years & 153 & 121.9 \\
ROD2 & 1182 & $\sim 6$ years & 121.9 & 144.1 \\
ROD3 & 892 & $\sim 6$ years & 93.9 & 108.7 \\
ROD4 & 5661 & $\sim 10$ year & - & 531.4 \\
\hline Total & 7901 & - & & 809.6 \\
\hline
\end{tabular}

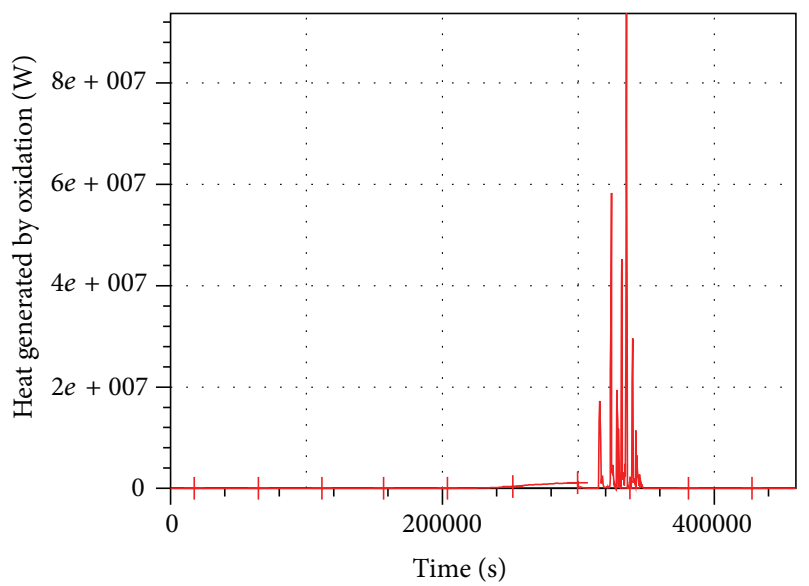

(a)

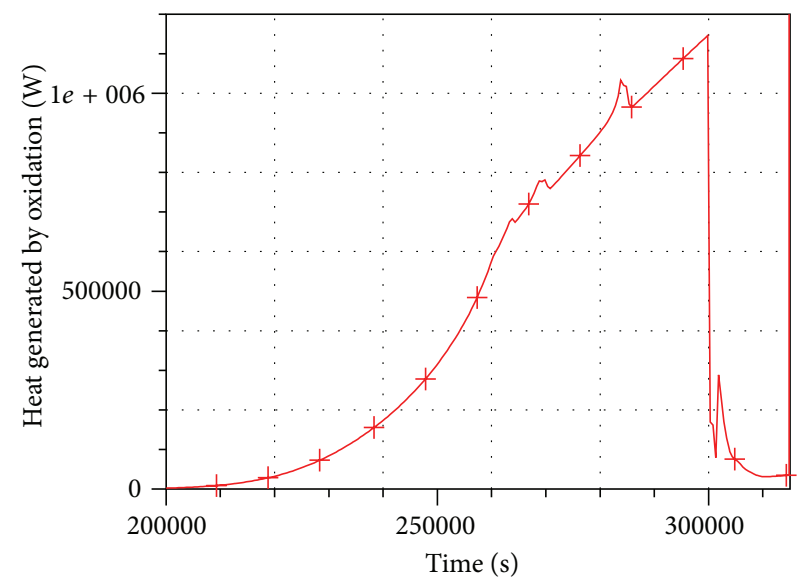

(b)

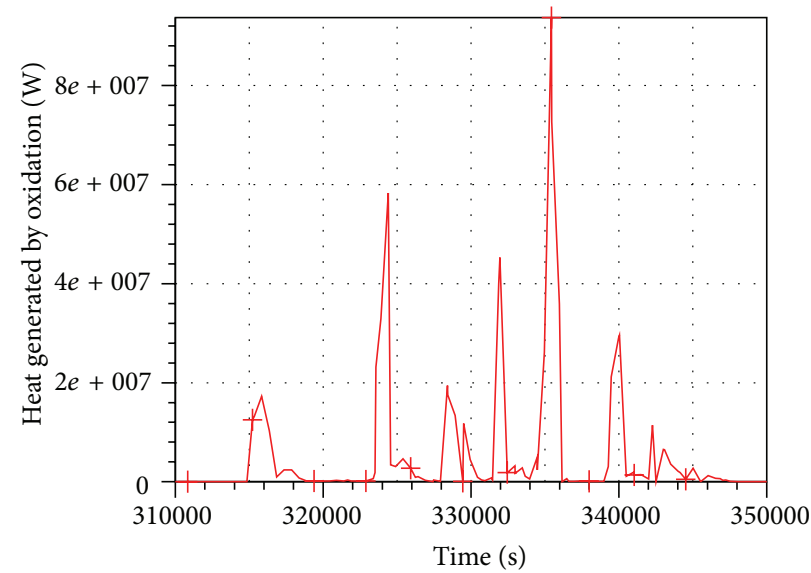

(c)

FIGURE 7: Heat generated by oxidation: (a) heat generation due to fuel cladding oxidation in air and steam during whole period of accident, (b) slow heat generation due to fuel cladding oxidation at temperature below $1200^{\circ} \mathrm{C}$ heat generation due to intensive fuel cladding oxidation in steam at temperature higher than $1200^{\circ} \mathrm{C}$.

removal from SFP of both units. The same conclusion for the similar accident conditions (loss of water from SFP after 4 years of final reactor shutdown) can be done for NPPs with other types generating 2 water cooled reactors (PWR, BWR, CANDU) because the decay heat of fuel elements will be approximately the same (BWR and PWR) or less (CANDU) and fuel assemblies approximately 2 times shorter, while heat removal conditions will be similar.

\section{Benchmarking of the ATHLET-CD Calculation Results with ASTEC and RELAP/SCDAPSIM}

Benchmark calculation using ASTEC and RELAP/ SCDAPSIM codes was done for the same accident as described in Section 3-water leakage and further water injection to the SFP. The same initial conditions, water leakages and injection 


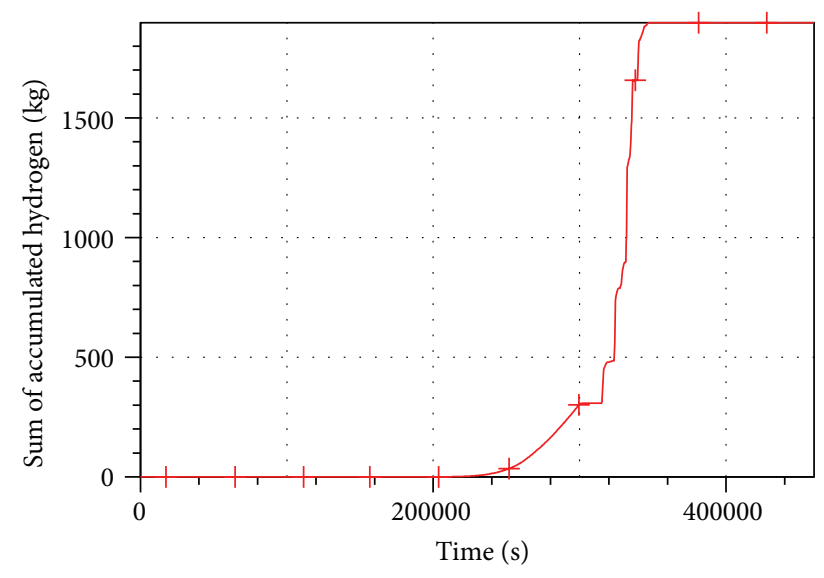

Figure 8: Hydrogen generation.

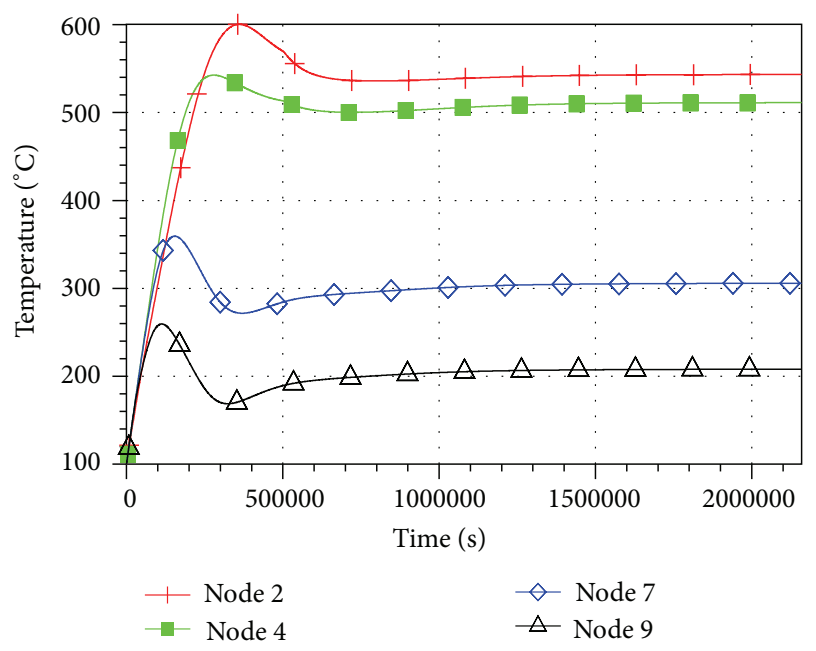

FIGURE 9: Temperatures of fuel in fuel assemblies ROD1.

times, and flow rates, as for the above described ATHLET$\mathrm{CD}$, were used for the ASTEC and RELAP/SCDAPSIM codes.

In case of spent fuel pools emptying oxidation in air is evaluated in ATHLET-CD and ASTEC models. The RELAP/SCDAPSIM Mod 3.2 does not evaluate the air oxidation phenomena. In ATHLET-CD for the oxidation Sokolov ( $\mathrm{Zr} \mathrm{1 \%} \mathrm{Nb),} \mathrm{oxidation} \mathrm{correlation} \mathrm{is} \mathrm{used} \mathrm{which}$ is recommended by ATHLET-CD code developer for fuel claddings $\mathrm{Zr} 1 \% \mathrm{Nb}$ (VVER, RBMK fuel element claddings) and Powers (NUREG1) correlation for oxidation in air. In ASTEC calculations, Urbanic-Heidrick oxidation correlation is used. To deal with $\mathrm{Zr}$ oxidation by air, two kinds of modifications have been done in ASTEC code: they concern fluid properties and reaction kinetics (for oxidation in air NUREG1 correlation is used).

In Figure 11 the comparison of temperatures on different levels in the spent fuel pool calculated by different codes is presented.

Figure 11 shows good agreement of calculation results of fuel temperatures in central parts of SFA, received using different computer codes. Maximal reached fuel temperature

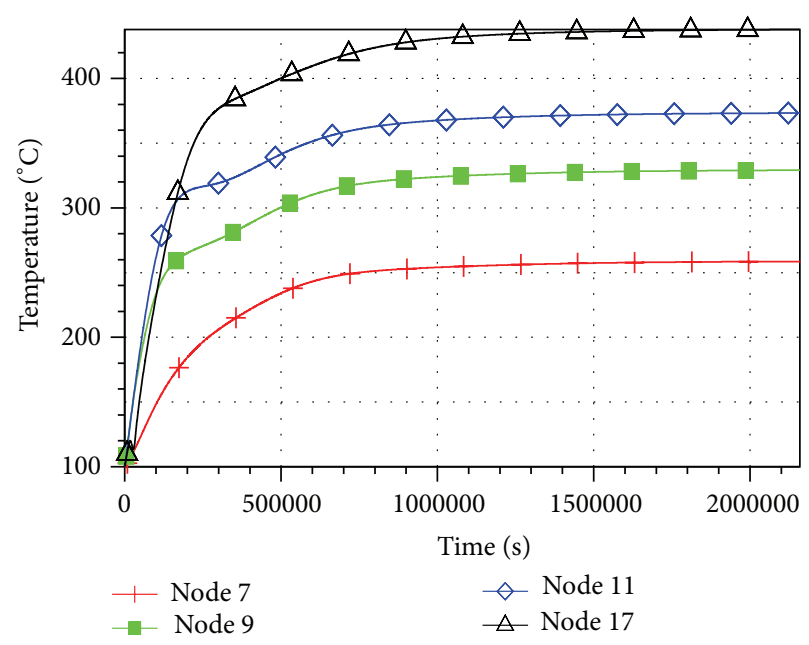

FIgURE 10: Temperatures of fuel in fuel assemblies ROD4.

in ATHLET-CD calculations is equal to $1900^{\circ} \mathrm{C}$, in ASTEC $2100^{\circ} \mathrm{C}$, in RELAP/SCDAPSIM $2200^{\circ} \mathrm{C}$. Only in the top part of SFAs, some disagreement between ATHLET-CD and RELAP/SCDAPSIM and ASTEC code calculation results exists. This inadequacy is due to the start of intensive oxidation (steam-zirconium reaction) in ASTEC code at lower temperature level. As a result, the highest values of fuel temperatures are reached in the bottom and central part of SFAs in ASTEC calculations. In ATHLET-CD calculations after water level decreases below the SFA bottom part (see Figure 5 at time moment $\sim 215,000$ s), no further water heats up by sources inside water while temperature is still below boiling point that leads to decrease of steam generation rate. At the same time temperature of SFA in central part reaches $600^{\circ} \mathrm{C}$ and slow oxidation process in steam and air already occurs. Due to these reasons, suction of air from SFP hall (TOPVOLUM element on Figure 3) occurs. This leads to a reverse of steam and air flow in SFP and to a decrease of temperature in top part of SFA (see temperature decrease in top part of SFA in ATHLET-CD calculation results in Figure 11(a) at time period from $\sim 215,000 \mathrm{~s}$ up to $\sim 225,000 \mathrm{~s}$ ). Due to the influence of hot air and steam mixture, SFP temperature of water in bottom part increases up to the boiling point $\left(100^{\circ} \mathrm{C}\right.$ reached at time moment $\left.\sim 225,000 \mathrm{~s}\right)$ and the increase of steam generation in bottom part leads to change of flow direction to the previous stage (from bottom to the top) and further increase of temperature of SFA occurs approximately with the same rate as in ASTEC calculations.

After the start of water injection $(t=300,000 \mathrm{~s})$, the node below SFA is filled with water. Later, the water level is increasing and water contacts the hot structures of SFAs in the first node. This leads to the very fast decrease of fuel rods temperature in this node. At the same time, a huge amount of steam is generated. The same process of fast fuel temperature decrease in this particular node and generation of steam will be repeated each time, after the water level reaches the next node. The generated steam is contacting with the heat structures in the nodes above. If the temperature of fuel rods in the nodes above is not 


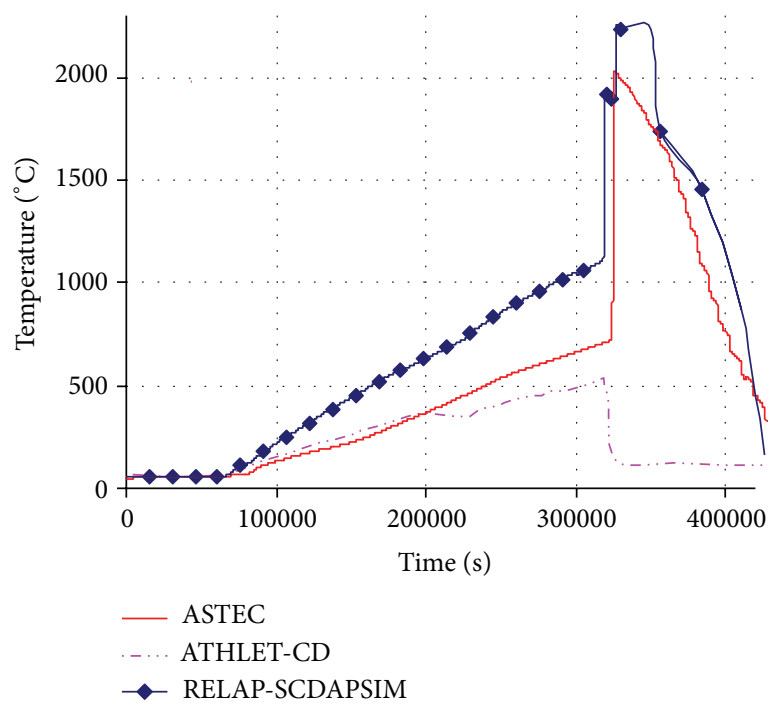

(a) Top part of SFA at elevation $10.82 \mathrm{~m}$ (node 17)

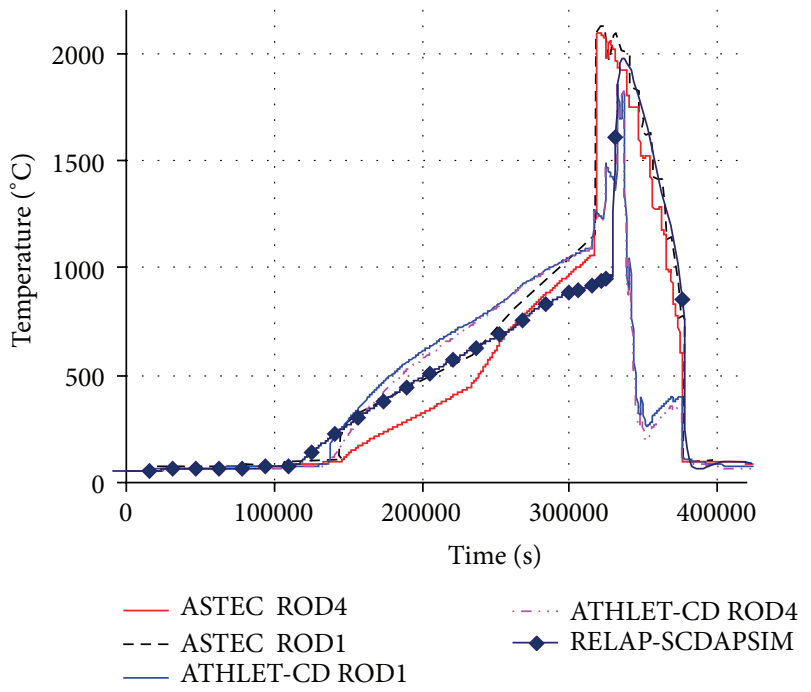

(b) Central part of SFA at elevation $5.64 \mathrm{~m}$ (node 10)

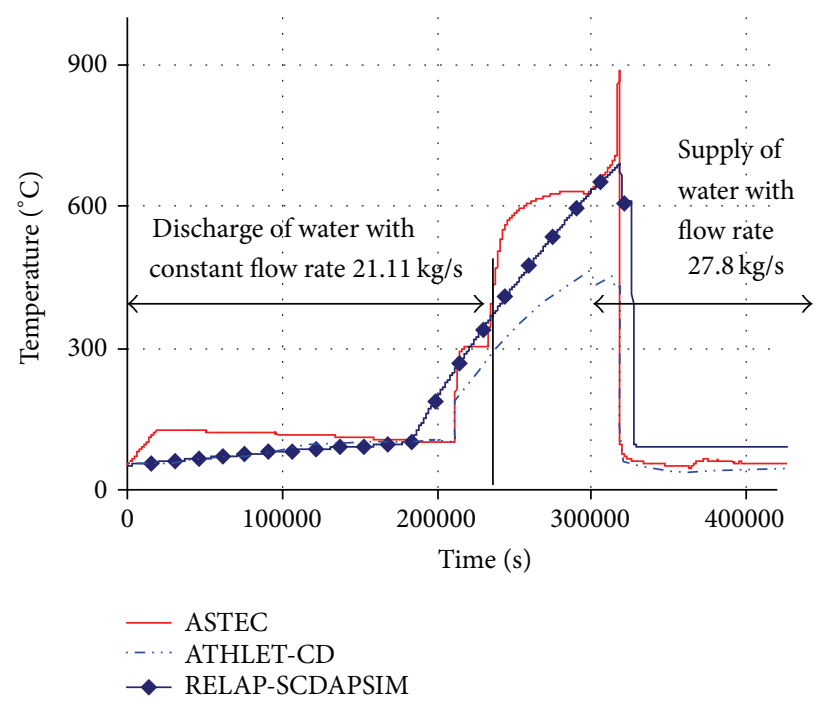

(c) Bottom part of SFA at elevation $1.17 \mathrm{~m}$ (node 2)

FIGURE 11: Fuel temperature in SFAs with different storage period at the different elevations calculated by using different codes (elevations from the bottom of SFA).

enough for fast steam-zirconium reaction, the generated steam cools down this part of SFAs (see temperature decrease in ATHLET-CD calculation in Figures 11(a) and 11(c) for all three codes calculations at time moment $\sim 315,000 \mathrm{~s}$ when huge amount of steam is generated). In the nodes with higher temperature (above temperature threshold for fast steamzirconium reaction), this leads to exothermic reaction and fuel temperature significantly increases (see Figure 11(b)).

Because the height of nodes is quite big (more than $0.5 \mathrm{~m}$ ), the amount of heat in each node is significant; thus, the increase (or decrease) of water level in the pool leads to stepwise behaviour of fuel rods temperature (Figure 11). In reality, steam will be generated gradually and behaviour of temperature should be smooth, not stepwise as it appears in the models.
In Figure 12, the comparison of generated hydrogen calculated by different codes is presented. In the ASTEC calculations total amount of hydrogen generated due to $\mathrm{Zr}$ oxidation after late supply of water in the SFP is about $5100 \mathrm{~kg}$, in RELAP/SCDAPSIM about $3800 \mathrm{~kg}$, and in ATHLETCD calculation is about $1900 \mathrm{~kg}$. Differences in results of hydrogen generation exist due to temperature changes in the top part of SFA: in ASTEC and RELAP/SCDAPSIM calculations rapid increase of temperature in top part and oxidation occurs while in ATHLET-CD calculation oxidation do not start here. As it is shown in paper [10] is the hydrogen generation in ASTEC code during fuel cladding oxidation at temperature range over $2000^{\circ} \mathrm{C}$ is overestimated from 10 to 30 percent; therefore, total amount of generated hydrogen could be between 3600 and $4500 \mathrm{~kg}$. 
TABLE 4: Sequence of events, in the case of water leakage from spent fuel pools of Ignalina NPP.

\begin{tabular}{|c|c|c|c|c|}
\hline Time ATHLET-CD & Time ASTEC & Time RELAP/SCDAPSIM & Events & Comments \\
\hline 0 & 0 & 0 & Start of water leakage from the spent fuel pools & (1) \\
\hline $60,000 \mathrm{~s}(16.7 \mathrm{~h})$ & $60,000 \mathrm{~s}$ & $60,000 \mathrm{~s}$ & $\begin{array}{l}\text { The uncovering of fuel starts. Start of fuel heat } \\
\text { up process }\end{array}$ & (2) \\
\hline $210,000 \mathrm{~s}(58.3 \mathrm{~h})$ & $240,000 \mathrm{~s}$ & $220,000 \mathrm{~s}$ & $\begin{array}{l}\text { The peak temperature of fuel reaches } \\
650-700^{\circ} \mathrm{C} \text {. Steam-zirconium reaction starts }\end{array}$ & (3) \\
\hline $215,000 \mathrm{~s}(59.7 \mathrm{~h})$ & $215,000 \mathrm{~s}$ & $215,000 \mathrm{~s}$ & All SFAs are uncovered & \\
\hline $235,000 \mathrm{~s}(65.3 \mathrm{~h})$ & $235,000 \mathrm{~s}$ & $215,000 \mathrm{~s}$ & The water leakage is terminated & $(4)$ \\
\hline $300,000 \mathrm{~s}(83.3 \mathrm{~h})$ & $300,000 \mathrm{~s}$ & $300,000 \mathrm{~s}$ & Water injection starts & $(5)$ \\
\hline $315000 \mathrm{~s}(87.5 \mathrm{~h})$ & $315000 \mathrm{~s}$ & $305000 \mathrm{~s}$ & $\begin{array}{l}\text { Water level increase up to the bottom part of } \\
\text { SFA. Start of fast steam generation and fast } \\
\text { exothermic oxidation }\end{array}$ & (6) \\
\hline $325,000 \mathrm{~s}(90.2 \mathrm{~h})$ & $317500 \mathrm{~s}$ & $318000 \mathrm{~s}$ & $\begin{array}{l}\text { The peak temperature of fuel in central part } \\
\text { reaches } 1500^{\circ} \mathrm{C} \text {. Melting of stainless steel } \\
\text { (distancing grids). Damages of fuel rods }\end{array}$ & $(7),(8),(9)$ \\
\hline $333,000 \mathrm{~s}(92.5 \mathrm{~h})$ & $319000 \mathrm{~s}$ & $325000 \mathrm{~s}$ & $\begin{array}{l}\text { The peak temperature of fuel in central part } \\
\text { reaches maximum }\end{array}$ & (10) \\
\hline $441000 \mathrm{~s}(122.5 \mathrm{~h})$ & $440000 \mathrm{~s}$ & $417,000 \mathrm{~s}$ & All SFA are flooded by water & (11) \\
\hline
\end{tabular}

Comments:

(1) It is that assumed constant water leakage flow rate is $21.1 \mathrm{~kg} / \mathrm{s}$.

(2) The uncovering of fuel leads to increase in gamma radiation.

(3) Due to overheating of uncovered fuel assemblies, the oxidation of zirconium and hydrogen generation begins.

(4) Modelling assumption: small part of water at the bottom of the pool still remains.

(5) Water injection flow rate $27.8 \mathrm{~kg} / \mathrm{s}$ is assumed taking into account the capacity of water makeup system in Ignalina NPP.

(6) Fast steam generation starts due to contact of water with hot bottom part of SFAs. Start of fast steam-zirconium reaction.

(7) Distancing grids at the ends of the SFA produced from the zirconium and niobium alloy; therefore melting of stainless steel distancing grids in central part does not lead to fuel rods dropping from SFA. Release of radioactive fission product starts.

(8) Zirconium and stainless steel grids in the SFAs are not modelled.

(9) Due to overheating of claddings in the long term the embrittlement and failure of claddings should appear earlier, comparing to ATHLET-CD calculations.

(10) Relocation of melted claddings starts, after reaching $1900^{\circ} \mathrm{C}$ temperature.

(11) Temperature of melted material and all SFA decreases below $100^{\circ} \mathrm{C}$.

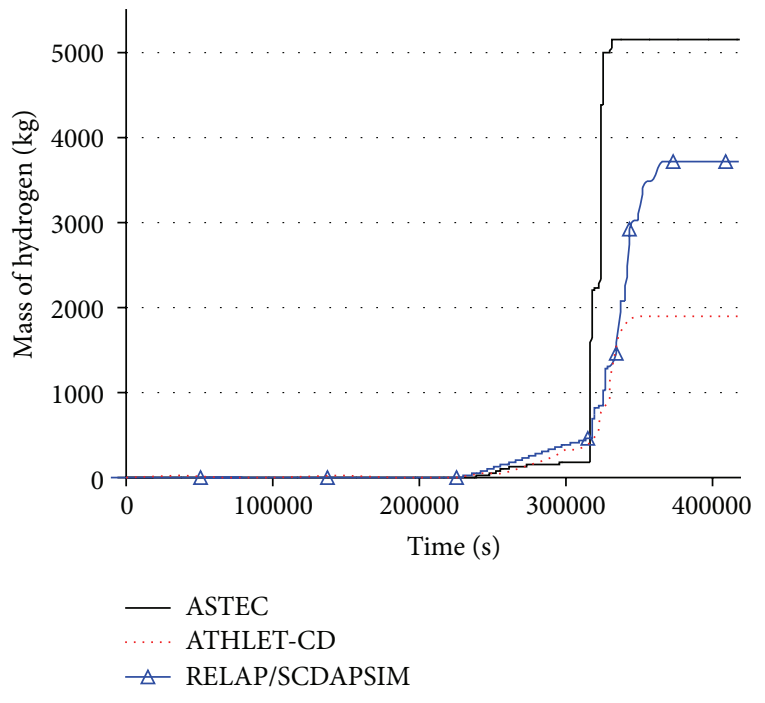

FIGURE 12: Hydrogen generation calculated by different codes.

Main sequence of events, in the case of water leakage from spent fuel pools in Ignalina NPP, calculated using ATHLETCD, ASTEC, and RELAP/SCDAPSIM codes, is presented in Table 4. From the results presented in the table, we can see that the sequence of events during severe accident in SFP is modelled with good agreement, the calculated times of events are very close using ATHLET-CD, ASTEC, and RELAP/SCDAPSIM models, developed for SFP of Ignalina NPP Unit 2. The results of performed analyses can be useful for creating severe accident guidelines for the evaluation of different accident mitigation measures.

\section{Conclusions}

This paper presents the calculation results of the most probable severe accident in spent fuel pools-loss of heat removal due to water leakage in SFP. Analysis of this event, which covers all possible phenomena in SFPs, was performed for SFP at Ignalina NPP Unit 2. For the analysis of the accident, the model of spent fuel pools was developed using different computer codes for the modelling of severe accidents in light water reactors ATHLET-CD, ASTEC, and RELAP/SCDAPSIM.

The developed models allowed to model different phenomena: uncovering and heat up of fuel rods, steamzirconium reaction, quenching of hot fuel rods by water, and so forth. This model can be used for SFP of different reactor types analysis, taking into account the SFP real technical parameters. 
Benchmarking of ATHLET-CD calculation results with calculations performed by RELAP/SCDAPSIM and ASTEC codes shows good agreement of the calculated behaviour of fuel temperatures. Some disagreement of hydrogen mass generation exists in ATHLET-CD with ASTEC and RELAP/SCDAPSIM calculation results because, in ASTEC calculation, the intensive oxidation starts at lower temperatures in comparison with ATHLET-CD. This leads to an overestimation of hydrogen generation at high temperatures in ASTEC calculation. Also the difference in hydrogen generation is due to differences in temperature behaviour in top part of SFA. The performed analyses are useful for the evaluation of different accident mitigation measures. The analyses were performed for Ignalina NPP Unit 2 spent fuel pool, but it can be applied for SFPs of other reactor types.

\section{Nomenclature}

$\begin{array}{ll}\text { ASTEC: } & \begin{array}{l}\text { Accident source term evaluation code } \\ \text { ATHLET-CD: }\end{array} \\ & \begin{array}{l}\text { Code for the analysis of thermal } \\ \text { hydraulics of leaks and transients } \\ \text { with core degradation }\end{array} \\ \text { NPP: } & \text { Nuclear power plant } \\ \text { NRC: } & \text { Nuclear regulatory commission } \\ \text { RELAP/SCDAPSIM: } & \text { Integrated, mechanistic computer } \\ & \text { code, for modelling of severe } \\ & \text { accidents in light-water-reactors } \\ & \text { Russian abbreviation for } \\ \text { RBMK: } & \text { "Large-power channel-type reactor" } \\ & \text { Spent fuel assembly } \\ \text { SFA: } & \text { Spent fuel pool. }\end{array}$

\section{References}

[1] T. E. Collins and G. Hubbard, "Technical study of spent fuel pool accident risk at decommissioning nuclear power plants," Tech. Rep. NUREG-1738, NRC, Washington, DC, USA, 2001.

[2] U.S. Nuclear Regulatory Commission, "Operating experience feedback report: assessment of spent fuel cooling," Tech. Rep. NUREG-1275, NRC, Washington, DC, USA, February 1997.

[3] A. Kaliatka, V. Ognerubov, and V. Vileiniskis, "Analysis of the processes in spent fuel pools of Ignalina NPP in case of loss of heat removal," Nuclear Engineering and Design, vol. 240, no. 5, pp. 1073-1082, 2010.

[4] K. Almenas, A. Kaliatka, and E. Ušpuras, Ignalina RBMK1500. A Source Book. Extended and Updated Version, Lithuanian Energy Institute, Kaunas, Lithuania, 1998.

[5] A. Kaliatka, V. Ognerubov, M. Vaisnoras, E. Uspuras, and K. Trambauer, "Analysis of beyond design basis accidents in spent fuel pools of the ignalina NPP," in Proceedings of International Conference on Advances in Nuclear Power Plants (ICAPP ¿08), pp. 1566-1575, Anaheim, Calif, USA, June 2008.

[6] K. Trambauer and H. Austregesilo, "Analysis of quenching during the TMI-2 accident with ATHLET-CD," in Proceedings of the 10th International Topical Meeting on Nuclear Reactor Thermal Hydraulics (NURETH '03), Seoul, Korea, 2003.

[7] J. van Dorsselaere, C. Seropian, P. Chatelard et al., "The ASTEC integral code for severe accident simulation," Nuclear Technology, vol. 165, no. 3, pp. 293-307, 2009.
[8] C. M. Allison and J. K. Hohorst, "Role of RELAP/SCDAPSIM in nuclear safety," Science and Technology of Nuclear Installations, vol. 2010, Article ID 425658, 17 pages, 2010.

[9] Institute VNIPIET, "Additional to Ignalina NPP design-safe storage of uranium-erbium fuel with enrichment of $2.8 \%$," Tech. Rep. 03-02499. TASpd-1299-70796, 2003.

[10] V. Vileiniskis and A. Kaliatka, "Best estimate analysis of PHEBUS FPT1 experiment bundle phase using ASTEC code ICARE module," Kerntechnik, vol. 76, no. 4, pp. 254-260, 2011. 


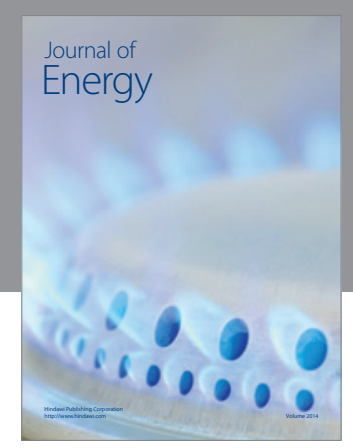

Journal of

Industrial Engineering
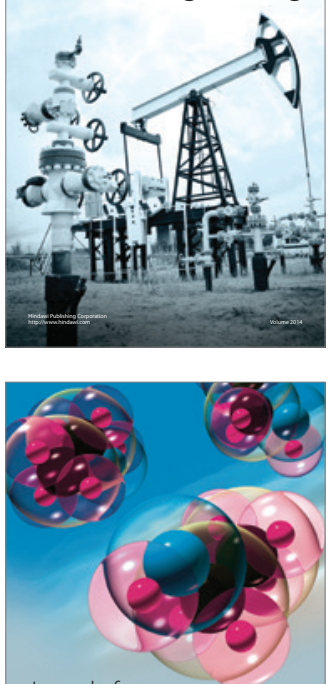

Fuels
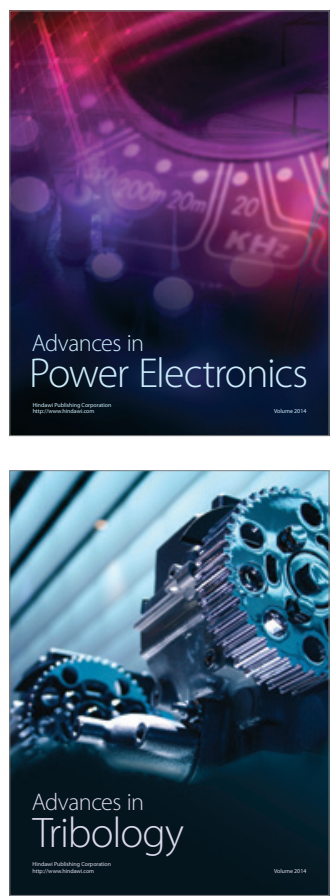

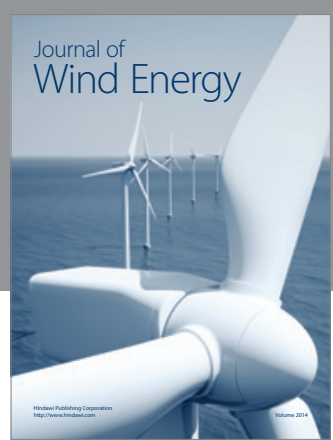

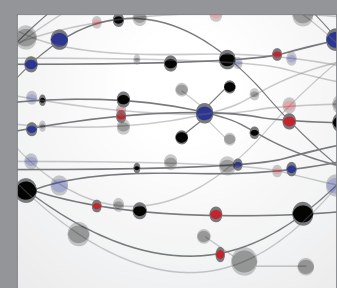

The Scientific World Journal

Submit your manuscripts at http://www.hindawi.com

Journal of

Structures
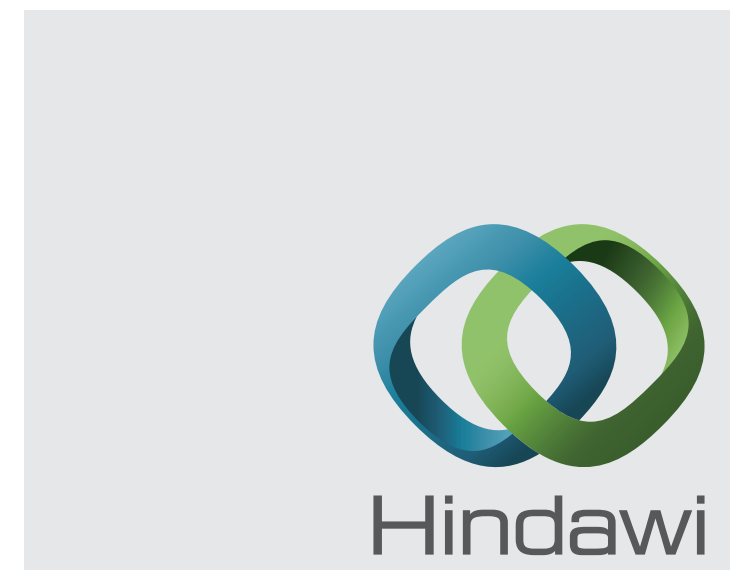

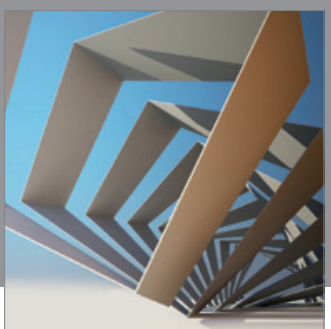

Rotating

Machinery
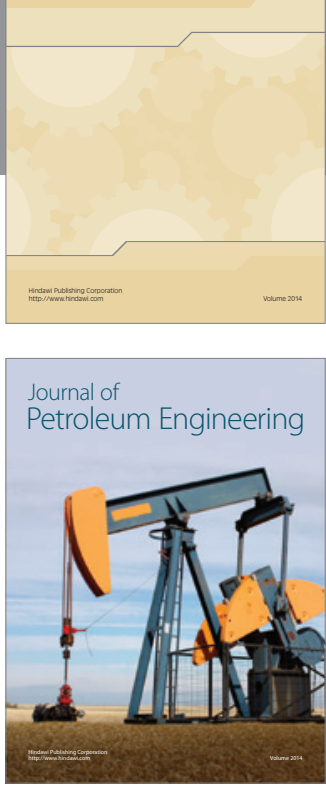

Journal of

Solar Energy
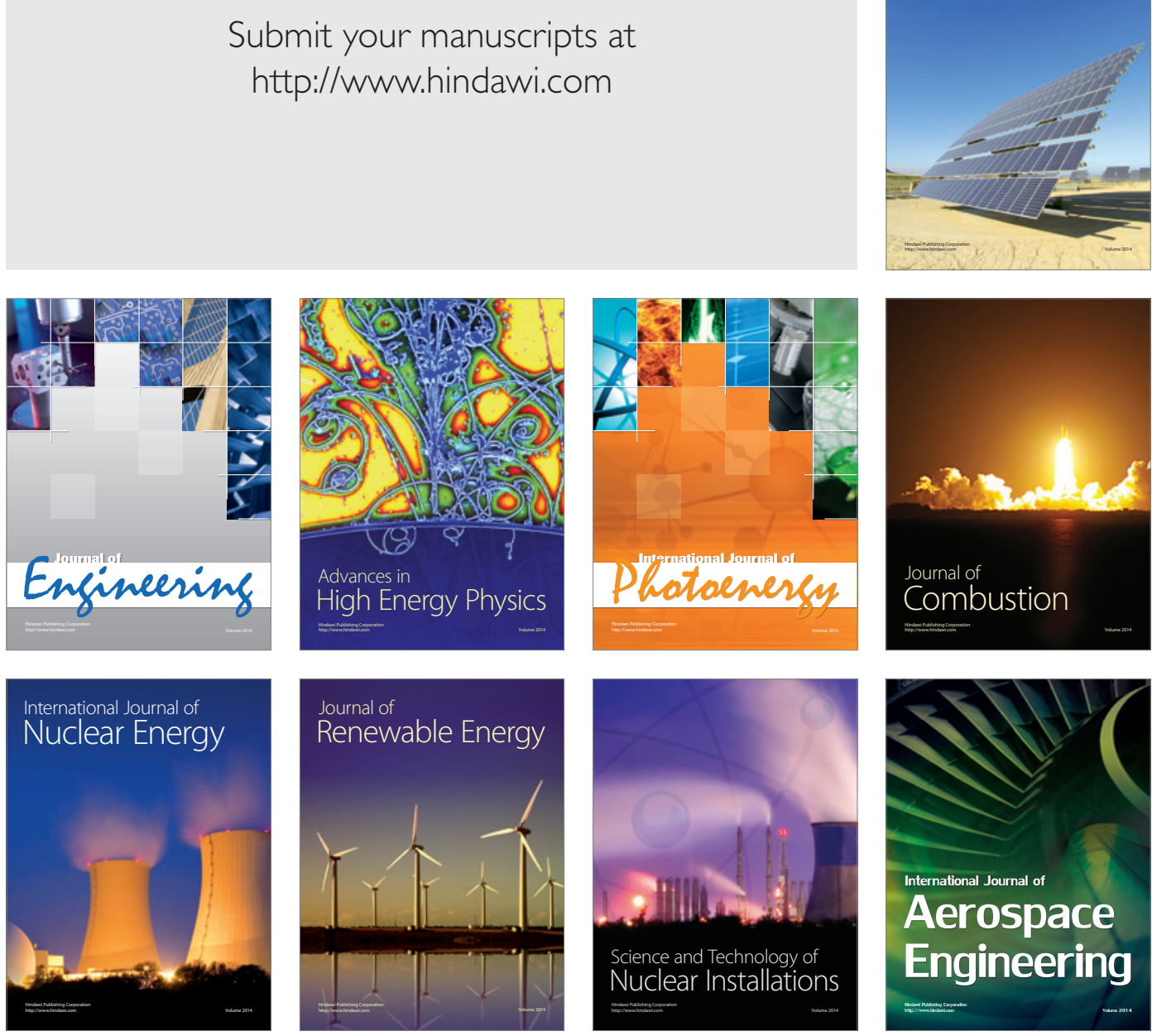